\title{
Irrigation Water Quality Assessment and Hydrochemical Facie of Oguta Lake, Southeastern Nigeria
}

\author{
F. M. Madu, E. I. Okoyeh, C. M. Okolo, P. Aseh, and U. F. Elomba
}

\section{ABSTRACT}

The quality of water for irrigation is important for maintaining soil properties and improving yields. This study assessed the quality of Oguta Lake for irrigation using irrigation indices of SAR, \% Na, PI, KI, and MH. Twenty (20) water samples were collected in the study area over two seasons and analyzed using standard methods. The results indicate that the water is excellent for irrigation with values of SAR, \% Na, PI, KI, and MH ranging between $0-0.007,0-0.18,213-329,0.0006-0.0022$, and $0.06-13$ in the dry season and 0.001-0.154, 0-3.57, 212-328, 0.008-0.0477 and 4.46-13.21 in the rainy season respectively. Piper and Durov diagrams were used to determine the hydrochemical facie of the water and both plots indicate that the water type is dominantly $\mathrm{Ca}^{2+}-\mathrm{Mg}^{2+}-\mathrm{HCO}_{3}{ }^{-}$and this water type is typical of fresh water. The piper plot also shows that weak acid exceeds strong acids and alkaline earth (dominant metal ions) exceeds alkalis. The concentration of major cations and anions follows the trend, $\mathrm{Ca}^{2+}>\mathrm{K}^{+}>\mathrm{Mg}^{2+}>\mathrm{Na}^{+}$and $\mathrm{HCO}_{3}>\mathrm{SO}_{4}{ }^{2-}>\mathrm{CO}_{3}^{-}>\mathrm{Cl}^{-}$, respectively.

Keywords: Hydrochemical facie, Irrigation water quality, Irrigation indices, Oguta Lake.
Published Online: January 08, 2022

ISSN: $2684-446 \mathrm{X}$

DOI : 10.24018/ejgeo.2022.3.1.221

\section{F. M. Madu*}

Department of Geosciences, Nnamdi Azikiwe University, Awka, Anambra state, Nigeria.

(e-mail: fm.madu@unizik.edu.ng)

E. I. Okoyeh

Department of Geosciences, Nnamdi Azikiwe University, Awka, Anambra state, Nigeria.

(e-mail: e.okoyeh ${ }^{@}$ unizik.edu.ng)

C. M. Okolo

Department of Geosciences, Nnamdi Azikiwe University, Awka, Anambra state, Nigeria.

(e-mail: cm.okolo ${ }^{\circledR}$ unizik.edu.ng)

P. Aseh

Department of Geosciences, Nnamdi Azikiwe University, Awka, Anambra state, Nigeria.

(e-mail: p.aseh ${ }^{@}$ unizik.edu.ng)

U. F. Elomba

Department of Geosciences, Nnamdi Azikiwe University, Awka, Anambra state, Nigeria.

(e-mail: uf.elomba ${ }^{@}$ unizik.edu.ng)

*Corresponding Author

\section{INTRODUCTION}

Surface water is the major source of water used in the agricultural sector in developing countries and the quality of water is extremely important for plant growth and productivity. Water quality is influenced by the composition and concentration of dissolved elements in the water; hence, its applicability for irrigation purpose is determined by the use of irrigation water quality indices.

The chemical composition of water plays a significant role in assessing the quality of water for irrigation [1] and these parameters include the major cations $\left(\mathrm{Na}^{+}, \mathrm{Ca}^{2+}, \mathrm{Mg}^{2+}, \mathrm{K}^{+}\right)$ and anions $\left(\mathrm{Cl}^{-}, \mathrm{SO}_{4}{ }^{2-}, \mathrm{HCO}_{3}{ }^{-} \mathrm{CO}_{2}{ }^{2-}, \mathrm{NO}_{3}{ }^{-}\right)$. Irrigation water quality indices such as Sodium Adsorption Ratio (SAR), Sodium Percentage (SSP; \%Na), Kelly's Ratio (KR) [or Kelly's Index (KI)], Permeability Index (PI), and Magnesium Hazard (MH) (or magnesium adsorption ratio; MAR), are frequently used to determine the quality of water for irrigation [2]-[4].
Therefore, this paper evaluates the hydrochemical facie and the quality of Oguta Lake for irrigation using these indices in other to improve agricultural productivity in the study area.

\section{A. Location of the Study Area}

Oguta Lake is located in Imo state, and it is bounded by Latitudes $05^{\circ} 40^{\prime}$ and $05^{\circ} 44^{\prime} \mathrm{N}$ and Longitudes $06^{\circ} 46^{\prime}$ and $06^{\circ}$ 50 'E, with an elevation of $50 \mathrm{~m}$ above sea level. The lake occupies a surface area, which ranges between $1.8 \mathrm{~km}^{2}$ in dry season and $2.5 \mathrm{~km}^{2}$ in the peak of rainy season, with maximum and mean depths of $8.0 \mathrm{~m}$ and $5.5 \mathrm{~m}$, respectively [5]. The lake covers $61.2 \%$ of the total surface area while the degraded portions cover the remaining $38.8 \%$ [6]. The degraded portion includes areas under intense human activities $(36.91 \%)$, areas covered by sediments $(1.39 \%)$, and eutrophication $(0.5 \%)$. 


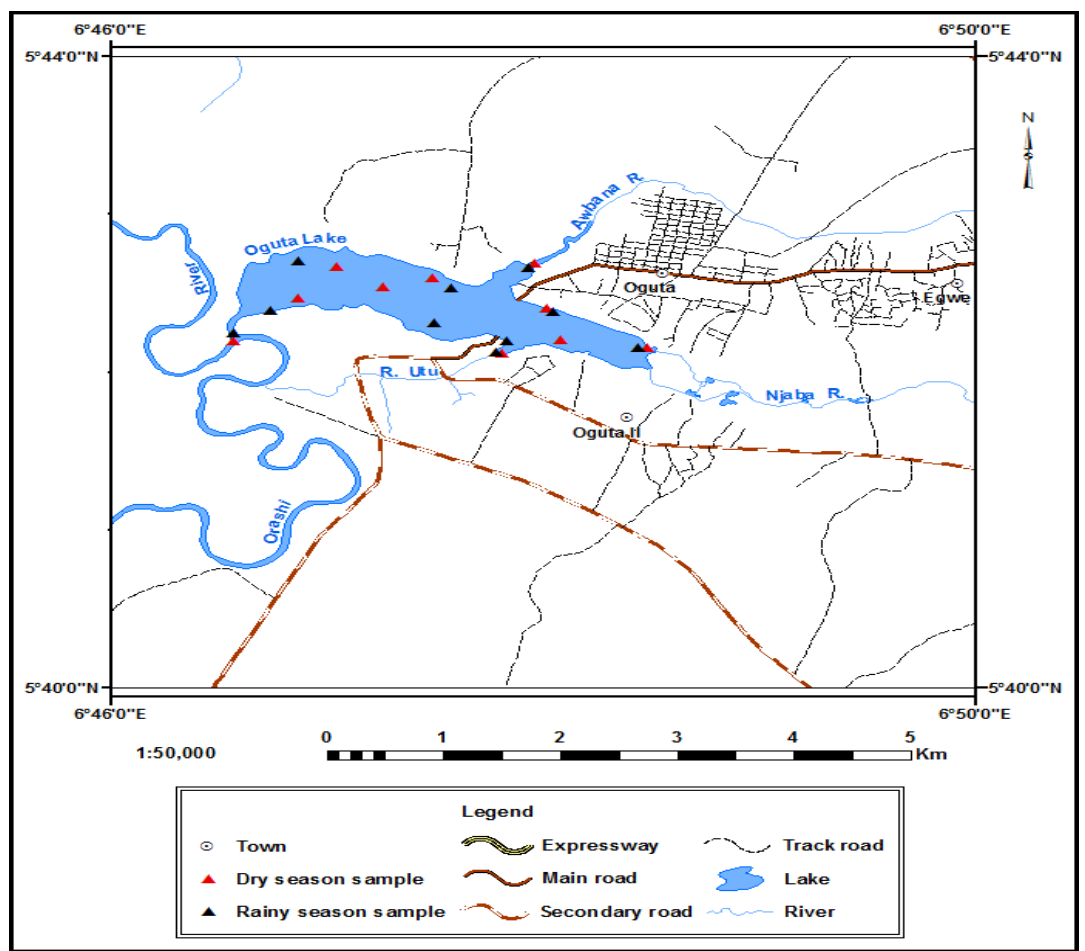

Fig 1. Map of the study area showing the different sampling locations for dry and rainy seasons.

\section{B. Geology and Hydrogeology of the Study Area}

The study area lies within the Niger Delta Basin, which consists of three lithostratigraphic units, which are the Akata, Agbada, and the Benin Formations respectively. Oguta Lake lies predominantly on the Benin Formation which consists of continental sands with lenses of clay/shale and some isolated units of gravel, conglomerate, and sandstones [7]. The Formation is Oligocene to recent in age [8].

There are four rivers (Njaba, Awbana, Utu and Orashi) that are associated with Oguta Lake [9] and these rivers play a significant role in its recharge. Njaba and Awbana Rivers discharges into the lake all year round, the perennial Utu Stream flows into the lake during the rainy season while Orashi River flows past the lake in its southwestern portion. The total annual inflow from the rivers and stream is estimated to be $25,801.60 \mathrm{~m}^{3}$ [6]. The annual return and overland flow into the lake is also estimated to be $69,000 \mathrm{~m}^{3}$ and $138,000 \mathrm{~m}^{3}$, respectively [10] while the annual recharge of the lake from precipitation is about $693,000 \mathrm{~m}^{3}$. The annual groundwater inflow into the lake is also estimated at $2,750,400 \mathrm{~m}^{3}$ [6]. These statistics show that Oguta Lake is adequately recharged all the year-round.

\section{MATERIALS AND METHODS}

\section{A. Sample Size and Sampling Procedure}

Twenty (20) water samples were collected over two seasons (dry and rainy seasons). The water samples were collected in one-liter plastic sample bottles. The bottles were rinsed three times using the lake water before collecting the samples. After collection, the sample bottles were corked immediately underwater to prevent oxidation. Each sample was properly labeled at the point of collection and stored in a cool box with ice cubes and transported to the laboratory for analysis.

\section{B. Analysis}

The collected samples were analyzed for various physicochemical parameters using standard methods [11]. Distilled water was used in the preparation of solutions and rinsing of all equipment after use. In-situ measurements of electrical conductivity, $\mathrm{pH}$, and turbidity were carried out using EC meter, $\mathrm{pH}$ meter, and turbidity meter respectively. Ultraviolet-visible spectrophotometer was used to analyze for nitrate, flame photometer was used to analyze sodium and potassium, Argentometric method was used to determine chloride, and volumetric titration against ethylenediamine tetra-acetic acids (EDTA) is used for magnesium and calcium ions.

\section{RESULTS AND DISCUSSION}

The physical parameters were all within WHO acceptable limit in both seasons. $\mathrm{pH}$ values vary between 6.51 to 6.95 in the dry season and 6.50 to 6.98 in the rainy season, with mean values of $6.708 \pm 0.12$ and $6.74 \pm 0.15$, respectively. Electrical conductivity values vary between 12 to 104.7 in the dry season and 10.6 to 105.8 in the rainy season, with mean values of $78.03 \pm 35.81$ and $78.75 \pm 36.51$, respectively while turbidity values vary between 0.4 to 20.6 in the dry season and 0.8 to 23.3 in the rainy, with mean values of $3.97 \pm 6.52$ and $4.79 \pm 7.44$, respectively.

The chemical parameters were also within the acceptable limits in both seasons. Among the cations, the concentration of $\mathrm{Ca}^{2+}, \mathrm{Mg}^{2+}, \mathrm{Na}^{+}$and $\mathrm{K}^{+}$ranges between 2.089-4.893, $0.095-0.2063,0-0.01$ and $2.089-3.098$, respectively in dry season and 2.0692-4.896, 0.096-0.268, 0.001-0.026 and $2.080-3.188$ respectively in rainy season. Among the anions, the concentration of $\mathrm{Cl}^{-}, \mathrm{HCO}_{3}{ }^{-}, \mathrm{NO}_{3}{ }^{-}$, and $\mathrm{SO}_{4}{ }^{2-}$ ranges between $27-37,73.2167 .75,8.925-18.443$ and 58.64111.23 , respectively for dry season and 24.8-36.4, 72$165.75,8.625-15.463$ and $60.54-118.25$ respectively for rainy season. 
TABLE I: THE CONCENTRATION OF THE PHYSICOCHEMICAL PARAMETERS OF WATER IN DRY AND RAINY SEASON

\begin{tabular}{|c|c|c|c|c|c|c|c|}
\hline \multicolumn{4}{|c|}{ Dry season } & \multicolumn{4}{|c|}{ Rainy season } \\
\hline Parameters & Minimum & Maximum & Mean \pm SD & Minimum & Maximum & Mean \pm SD & WHO 2008 \\
\hline $\mathrm{pH}$ & 6.51 & 6.95 & $6.708 \pm 0.12$ & 6.5 & 6.98 & $6.74 \pm 0.15$ & $6.5-8.5$ \\
\hline Turbidity NTU & 0.4 & 20.6 & $3.97 \pm 6.52$ & 0.8 & 23.3 & $4.79 \pm 7.44$ & 5 \\
\hline Conductivity us/cm & 12.0 & 104.7 & $78.03 \pm 35.81$ & 10.6 & 105.8 & $78.75 \pm 36.51$ & 500 \\
\hline Chloride mg/l & 27.0 & 37.0 & $32.25 \pm 3.55$ & 24.8 & 36.4 & $30.82 \pm 3.79$ & 200 \\
\hline Nitrate mg/l & 8.925 & 18.443 & $12.7629 \pm 2.70$ & 8.625 & 15.463 & $12.29 \pm 2.06$ & 50 \\
\hline Sulphate mg/l & 58.64 & 111.23 & $71.727 \pm 15.70$ & 60.54 & 118.25 & $74.75 \pm 16.53$ & $250-500$ \\
\hline Magnesium mg/l & 0.095 & 0.263 & $0.1457 \pm 0.05$ & 0.096 & 0.268 & $0.1546 \pm 0.05$ & 150 \\
\hline Sodium mg/l & 0.00 & 0.010 & $0.004 \pm 0.004$ & 0.001 & 0.026 & $0.0319 \pm 0.06$ & 200 \\
\hline Potassium mg/l & 2.089 & 3.098 & $2.4505 \pm 0.36$ & 2.080 & 3.188 & $2.4944 \pm 0.39$ & 50 \\
\hline Calcium mg/l & 2.089 & 4.893 & $3.4756 \pm 0.88$ & 2.069 & 4.896 & $3.4895 \pm 0.90$ & 75 \\
\hline Bicarbonate mg/l & 73.2 & 167.75 & $97.905 \pm 27.10$ & 72.0 & 165.75 & $95.87 \pm 27.55$ & 250 \\
\hline Carbonate mg/l & 36 & 82.5 & $48.15 \pm 13.63$ & 33.5 & 80.20 & $46.749 \pm 13.62$ & \\
\hline
\end{tabular}

\section{A. Hydrochemical Facies}

Hydrochemical facies are distinct zones that describe the dominant cations and anions that influences hydrochemistry in water. The hydrochemical facies of the water samples from the study area was determined by plotting the results of the analytical data on a Piper (Fig. 2) and Durov (Fig. 4) diagrams using grapher software. Piper Trilinear Diagram [12] comprises of 2 triangles and a diamond, with the left and right triangle demonstrating the concentration of cations and anions which were expressed in meq/l. The plots in both triangles were then projected into the upper diamond-shaped field and similar water samples were identified because they are plotted as a cluster.

Durov diagram on the other hand, is a composite plot consisting of 2 ternary diagrams and a square. The ternary diagram on the left represents the cations: calcium, magnesium, and sodium + potassium while the ternary diagram at the top represents the anions: chloride, sulphate and carbonate + bicarbonate. The square plot is the projection of the cation and anion ternary plots with the concentrations expressed in milliequivalents percentages.

The data plots in the piper diagram shows that all the water samples fall in the $\mathrm{Ca}^{2+}-\mathrm{Mg}^{2+}-\mathrm{HCO}_{3}{ }^{-}$type, which is typical of fresh water and signifies that weak acid exceeds strong acids (i.e., $\mathrm{HCO}^{3}>\mathrm{Cl}+\mathrm{SO}^{4}$ ) and alkaline earth (dominant metal ions) exceeds alkalis (viz., $\mathrm{Ca}+\mathrm{Mg}>\mathrm{Na}+\mathrm{K}$ ). The dominant cation and anion are $\mathrm{Ca}^{2+}$ and $\mathrm{HCO}_{3}{ }^{-}$, respectively. The fact that $\mathrm{Ca}-\mathrm{Mg}-\mathrm{HCO}_{3}$ water type prevails in the study area was supported by data plotted on Durov diagram (Fig. 4 ), where $100 \%$ of the samples plotted in field two (2). Based on the classification of Lloyd and Heathcoat (1985), $\mathrm{HCO}_{3}{ }^{-}$ and $\mathrm{Ca}^{2+}$ are dominant in the water.

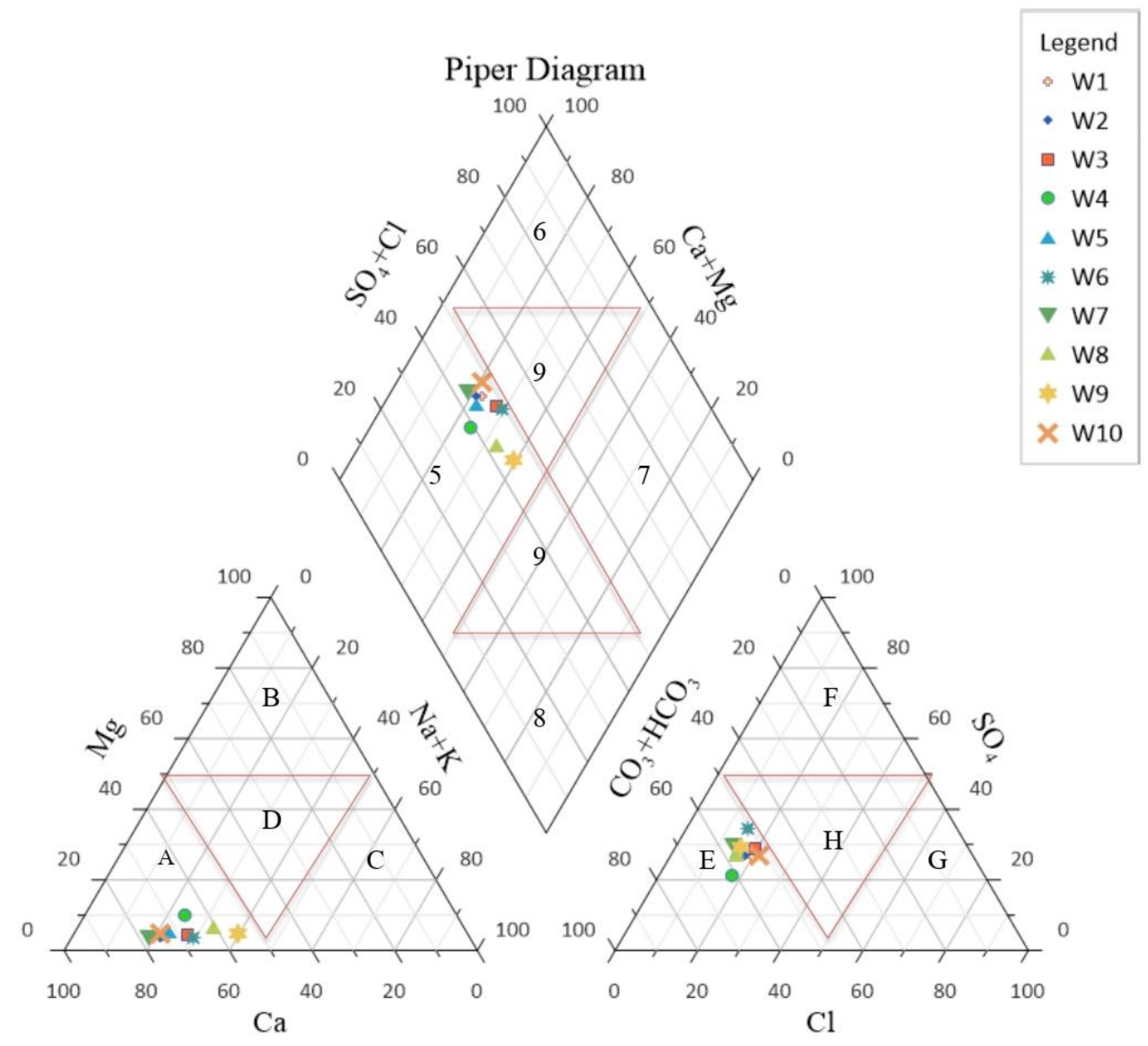

Fig. 2. Piper Plot of the water chemistry of Oguta Lake. 


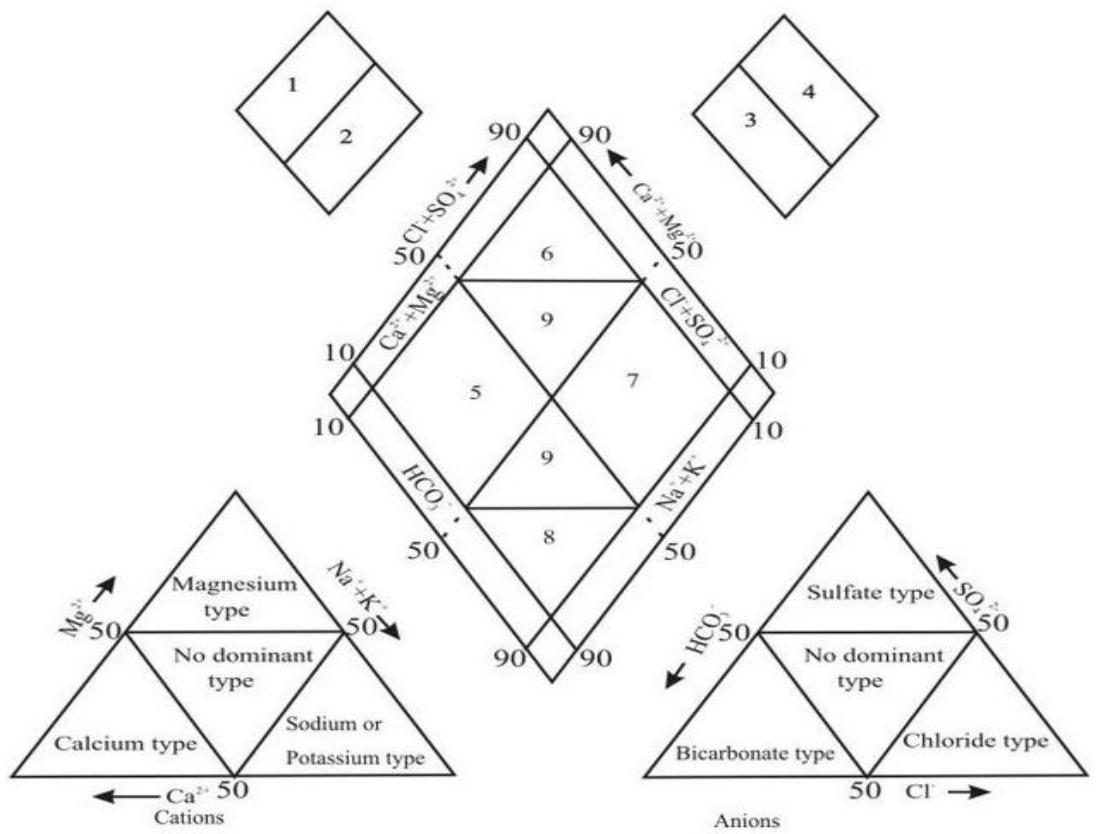

LEGEND

Hydrochemical Facies

(I) $\mathrm{Ca}^{2+}-\mathrm{Mg}^{2+}-\mathrm{Cl}^{-} \mathrm{SO}_{4}{ }^{2-}$

(II) $\mathrm{Na}^{+}-\mathrm{K}^{+}-\mathrm{Cl}^{2+}-\mathrm{SO}_{4}{ }^{2 \cdot}$

(III) $\mathrm{Na}^{+}-\mathrm{K}^{+}-\mathrm{HCO}_{3}{ }^{-}$

(IV) $\mathrm{Ca}^{2+}-\mathrm{Mg}^{2+}-\mathrm{HCO}_{3}{ }^{-}$

\section{Water Type}

1. $(\mathrm{Ca}+\mathrm{Mg})>(\mathrm{Na}+\mathrm{K})$

2. $(\mathrm{Na}+\mathrm{K})>(\mathrm{Ca}+\mathrm{Mg})$

3. $\left(\mathrm{CO}_{3}+\mathrm{HCO}_{3}\right)>\left(\mathrm{SO}_{4}+\mathrm{Cl}\right)$

4. $\left(\mathrm{SO}_{4}+\mathrm{Cl}\right)>\left(\mathrm{CO}_{3}+\mathrm{HCO}_{3}\right)$

5. $\mathrm{HCO}_{3}-\mathrm{CO}_{3}$ and $\mathrm{Ca}-\mathrm{Mg}$

(Temporary hardness)

6. $\mathrm{SO}_{4}-\mathrm{Cl}$ and $\mathrm{Ca}-\mathrm{Mg}$

(permanent hardness)

7. $\mathrm{SO}_{4}-\mathrm{Cl}$ and $\mathrm{Na}-\mathrm{K}$

(Saline)

8. $\mathrm{HCO}_{3}-\mathrm{CO}_{3}$ and $\mathrm{Na}-\mathrm{K}$

(Alkali carbonate)

9. Mixing zone

Fig. 3. Hydrochemical facies according to Back and Hanshaw, 1965.

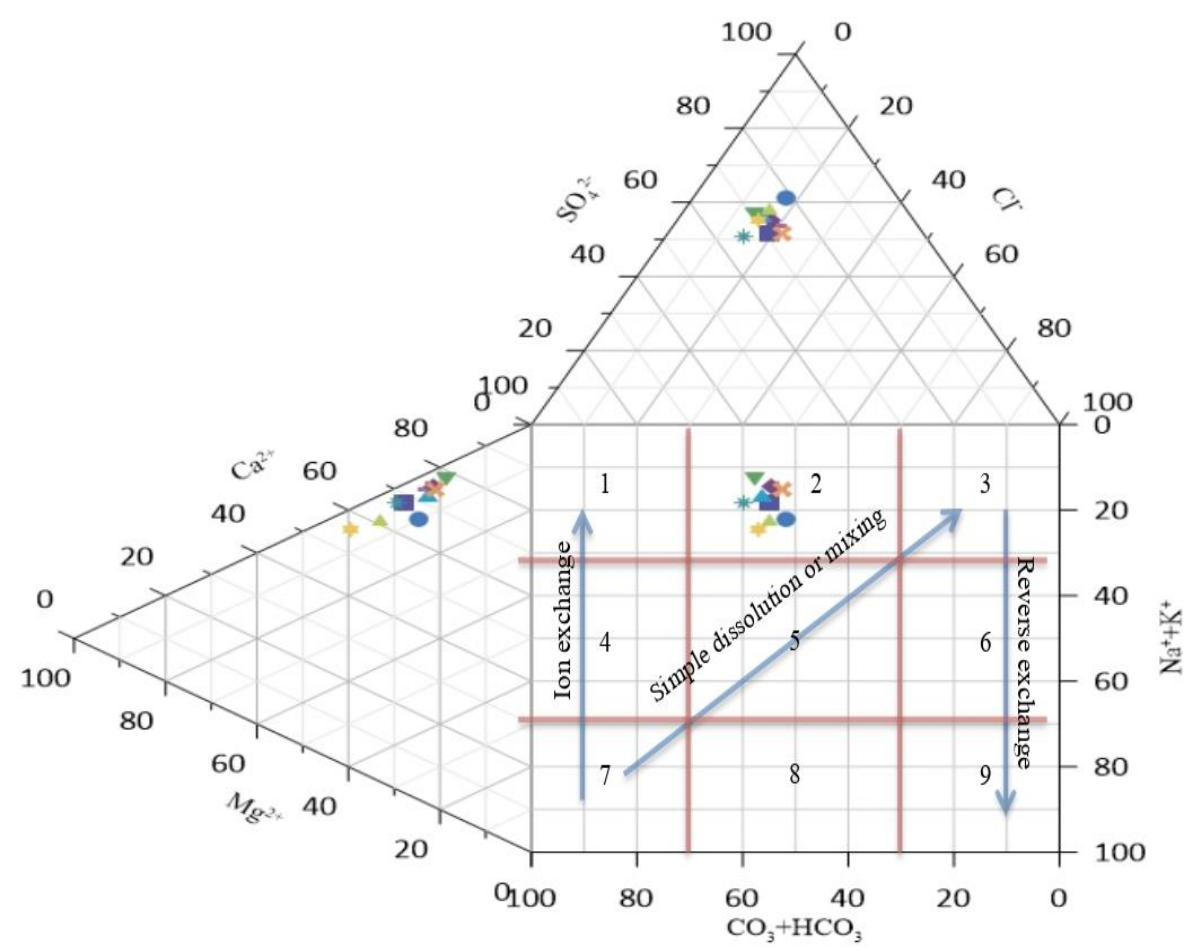

Fig. 4. Durov plot depicting the hydrochemical facie of the study area.

TABLE II. ClassiFicATION OF WATER BASED ON DUROV DiagRAM (LlOYd AND HEATHCOAT, 1985)

\begin{tabular}{|c|c|c|}
\hline $\mathbf{S} / \mathbf{N}$ & Water Type & $\%$ of Samples \\
\hline 1 & $\mathrm{HCO}_{3}$ and $\mathrm{Ca}$ are dominant and frequently indicate recharging waters in limestone, sandstone, and many other aquifers. & \\
\hline 2 & $\begin{array}{l}\mathrm{Ca} \text { and } \mathrm{HCO}_{3} \text { ions dominate this water type. Association with dolomite is presumed if } \mathrm{Mg} \text { is significant. However, those } \\
\text { samples in which Na is significant, an important ion exchange is presumed }\end{array}$ & $100 \%$ \\
\hline 3 & $\begin{array}{l}\mathrm{HCO}_{3} \text { and } \mathrm{Na} \text { are dominant, normally indicates ion exchanged water, although the generation of } \mathrm{CO}_{2} \text { at depth can produce } \\
\mathrm{HCO}_{3} \text { where } \mathrm{Na} \text { is dominant under certain circumstances. }\end{array}$ & ----- \\
\hline 4 & $\begin{array}{l}\mathrm{SO}_{4} \text { dominates, or anion discriminant and } \mathrm{Ca} \text { dominant, } \mathrm{Ca} \text { and } \mathrm{SO}_{4} \text { dominant, frequently indicates recharge water in lava } \\
\text { and gypsiferous deposits, otherwise mixed water or water exhibiting simple dissolution may be indicated. }\end{array}$ & \\
\hline 5 & No dominant anion or cation, indicates water exhibiting simple dissolution or mixing. & \\
\hline 6 & $\begin{array}{l}\mathrm{SO}_{4} \text { dominant or anion discriminate, and } \mathrm{Na} \text { dominant is a water type that is not frequently encountered and indicates } \\
\text { probable mixing or uncommon dissolution influences. }\end{array}$ & \\
\hline 7 & $\begin{array}{l}\mathrm{Cl} \text { and } \mathrm{Na} \text { dominant are frequently encountered unless cement pollution is present. Otherwise, the water may result from } \\
\text { reverse ion exchange of } \mathrm{Na}-\mathrm{Cl} \text { waters. }\end{array}$ & \\
\hline 8 & $\begin{array}{l}\mathrm{Cl} \text { dominant anion and } \mathrm{Na} \text { dominant cation, indicate that the ground waters be related to reverse ion exchange of } \mathrm{Na}-\mathrm{Cl} \\
\text { waters. }\end{array}$ & \\
\hline 9 & $\mathrm{Cl}$ and $\mathrm{Na}$ dominant frequently indicate end-point down gradient waters through dissolution & \\
\hline
\end{tabular}


TABLE III: THE VALUES OF THE IRRIGATION INDICES FOR THE VARIOUS SAMPLES IN DRY AND RAINY SEASON

\begin{tabular}{|c|c|c|c|c|c|c|c|c|c|c|c|}
\hline \multicolumn{6}{|c|}{ DRY SEASON } & \multicolumn{6}{|c|}{ RAINY SEASON } \\
\hline $\mathbf{S} / \mathbf{N}$ & SAR & $\% \mathrm{Na}$ & PI & KI & MH & $\mathbf{S} / \mathbf{N}$ & SAR & $\% \mathrm{Na}$ & PI & KI & MH \\
\hline D1 & 0 & 0 & 213 & 0 & 4.97 & R1 & 0.003 & 0.06 & 212 & 0.0008 & 5 \\
\hline D2 & 0.004 & 0.11 & 236 & 0.0144 & 4.75 & $\mathbf{R 2}$ & 0.018 & 0.40 & 231 & 0.0051 & 4.99 \\
\hline D4 & 0.007 & 0.18 & 282 & 0.0024 & 13 & R4 & 0.013 & 0.32 & 278 & 0.0042 & 13.21 \\
\hline D5 & 0.007 & 0.17 & 298 & 0.0022 & 0.06 & R5 & 0.154 & 3.57 & 288 & 0.0477 & 6.40 \\
\hline D6 & 0 & 0 & 293 & 0 & 5.21 & R6 & 0.002 & 0 & 293 & 0 & 5.21 \\
\hline D7 & 0.003 & 0.06 & 221 & 0.0008 & 4.12 & $\mathbf{R 7}$ & 0.003 & 0.06 & 222 & 0.0008 & 4.46 \\
\hline D8 & 0.002 & 0.04 & 288 & 0.0006 & 9.05 & R8 & 0.007 & 0.13 & 289 & 0.0019 & 9.78 \\
\hline D9 & 0 & 0 & 329 & 0 & 8.11 & R9 & 0.001 & 0 & 328 & 0 & 8.83 \\
\hline D10 & 0.005 & 0.12 & 233 & 0.0015 & 6.16 & R10 & 0.028 & 0.64 & 228 & 0.0082 & 7.26 \\
\hline
\end{tabular}

\section{B. Irrigation Indices}

This refers to those indices that are used to ascertain the suitability of water for irrigation purpose. These indices include sodium absorption ratio (SAR), Soluble sodium percentage $(\% \mathrm{Na})$, Permeability index (PI), Kelly Index (KI), and Magnesium hazard $(\mathrm{MH})$. The mean concentrations of $\mathrm{Na}^{+}, \mathrm{Ca}^{2+}, \mathrm{Mg}^{2+}, \mathrm{K}^{+}, \mathrm{HCO}^{-}$, and $\mathrm{CO}_{3}{ }^{2-}$ were used for the computation and all parameters were expressed in $\mathrm{Meq} / 1$.

\section{Sodium Hazard (SH)}

Sodium concentration is important in classifying irrigation water because sodium reacts with soil to reduce permeability [13]. The calculation of sodium absorption ratio (SAR) and soluble sodium percentage (SSP) was used to assess the sodium hazard of the samples.

\section{Sodium Absorption Ratio (SAR)}

Sodium adsorption ratio (SAR) is the proportion of sodium to calcium and magnesium, which affects the availability of water to crop. It is commonly used as an index for evaluating the sodium hazard associated with irrigation water. This is because high sodium content in irrigation water increases the exchangeable sodium content of the soil and disperses the soil more rapidly. The dispersed soil particles seal the soil macro pores and reduces the soil permeability. Under this condition, the water available to plant is also reduced appreciably. SAR was calculated using the equation given by [14] with the concentration of the ions expressed in meq/l.

$$
\mathrm{SAR}=\frac{N a^{+}}{\sqrt{\frac{C a^{2+}+M g^{2+}}{2}}}
$$

TABLE IV: CATEGORIZATION OF IRRIGATION WATER QUALITY BASED ON

\begin{tabular}{ccc} 
& \multicolumn{2}{c}{ SAR } \\
\hline Sodium & Range & Water class \\
\cline { 2 - 3 } Absorption & $<10$ & Excellent \\
Ratio (SAR) & $10-18$ & Good/Safe \\
& $18-26$ & Permissible/Moderate \\
& $>26$ & Unsuitable \\
\hline
\end{tabular}

The values of SAR range from 0 to 0.007 and 0.001 to 0.154 for dry and rainy seasons respectively, with mean values of 0.03 and 0.02 . Thus, $100 \%$ of the samples for both seasons have values $<10$ and these shows that the water is excellent for irrigation on the basis of SAR.

\section{E. Soluble Sodium Percentage (\% $\mathrm{Na}$ )}

The percentage of sodium ( $\mathrm{Na} \%)$, which is also known as soluble sodium percentage (SSP) is also used to assess the water quality for irrigation purpose. The high content of $\mathrm{Na}^{+}$ in the irrigation water cause direct impact on the plant growth and soil quality as well. Irrigation water with $\mathrm{Na} \%>60 \%$ may result in $\mathrm{Na}^{+}$accumulation and possibly a deterioration of soil structure, infiltration, and aeration.

Soluble sodium percentage (SSP) was calculated by employing the equation given by [13] and the ionic concentration of each cation expressed in meqL ${ }^{-1}$.

$$
\operatorname{SSP}(\% \mathrm{Na})=\frac{\left(\mathrm{Na}^{+}+\mathrm{K}^{+}\right)}{\left(\mathrm{Ca}^{2+}+\mathrm{Mg}^{2+} \mathrm{Na}^{+}+\mathrm{K}^{+}\right)} \times 100
$$

TABLE V: CATEGORIZATION OF IRRIGATION WATER QUALITY BASED ON $\% \mathrm{NA}$

\begin{tabular}{ccc}
\hline & Range & Water class \\
\cline { 2 - 3 } Sodium Percentage $(\% \mathbf{N a})$ & $<20$ & Excellent \\
& $20-40$ & Good \\
& $60-60$ & Permissible \\
& $>80$ & Doubtful \\
\hline
\end{tabular}

The values of the soluble sodium percentage ranges between 0 to 0.18 and 0 to 3.57 for dry and rainy season respectively, with mean values of $0.07 \%$ and $0.53 \%$. Thus, $100 \%$ of the samples for both seasons have values $<20$ and this indicates that the water is excellent for irrigation purpose on the basis of $\% \mathrm{Na}$.

\section{F. Permeability Index (PI)}

Permeability index (PI) is also used to assess the suitability of water for irrigation. Soil permeability is often influenced by water quality and the excessive use of water with high concentration of salt for irrigation impacts soil permeability and plant yield. The formula developed by [15] was used in the calculation of PI in the study area and it is expressed as;

$$
\mathrm{PI}=\sqrt{\frac{\mathrm{Na}^{+}+\sqrt{\mathrm{HCO}_{3}^{-}}}{\mathrm{Ca}^{2+}+\mathrm{Mg}^{2+}+\mathrm{Na}^{+}}} \times 100
$$

TABLE VI: CATEGORIZATION OF IRRIGATION WATER QUALITY BASED ON PERMEABILITY INDEX

\begin{tabular}{ccc}
\hline & Range & Water class \\
\cline { 2 - 3 } Permeability Index & $>75$ & Good-Class I \\
(PI) & $25-75$ & Good-Class II \\
& $<25$ & Unsuitable-Class III \\
\hline
\end{tabular}

The values of permeability index ranges from 213 to 329 in the dry season and 212 to 328 in the rainy season, with a mean value of 265.1 and 262.4 respectively. Thus, $100 \%$ of these values fall in Class I, which is good for irrigation purpose. 


\section{G. Kelly Index/Ratio}

This was introduced by [16] and it is another factor that is used to assess quality of water for irrigation purpose based on the concentration of $\mathrm{Na}+$ against $\mathrm{Ca}^{2+}$ and $\mathrm{Mg}^{2+}$. It was determined by using the equation below and all the concentration of ions are expressed in meq/l.

$$
\mathrm{KI}=\frac{\mathrm{Na}^{+}}{\mathrm{Ca}^{2+}+\mathrm{Mg}^{2+}}
$$

TABLE VII: CATEGORIZATION OF IRRIGATION WATER QUALITY BASED

\begin{tabular}{ccc} 
& ON KI & \\
\hline \multirow{3}{*}{ Kelly Ratio } & Range & Water class \\
\cline { 2 - 3 } & $<1$ & Suitable \\
& $>1$ & Unsuitable \\
\hline
\end{tabular}

The values of KR range from 0.0006 to 0.0022 and 0.0008 to 0.0477 for dry and rainy season respectively, with mean values of 0.0022 and 0.0071 . Thus, $100 \%$ of the samples for both seasons have values $<1$ and this shows that the water is suitable for irrigation on the basis of KR.

\section{H. Magnesium Hazard (MH)}

The magnesium hazard ( $\mathrm{MH})$ parameter was proposed by [17] and widely used to evaluate the water quality for irrigation. This was determined by using the equation below and the concentration of each cation was expressed in meq $\mathrm{L}^{-1}$. The value of $\mathrm{MH}>50$ means harmful and unsuitable for irrigation, while values of $\mathrm{MH}<50$ indicates suitable and not harmful for irrigation.

$$
\mathrm{MH}=\frac{\mathrm{Mg}^{2+}}{\left(\mathrm{Ca}^{2+}+\mathrm{Mg}^{2+}\right)} \times 100
$$

The result for magnesium hazard ranges from 0.06 to 13 and 4.46 to 13.21 for dry and rainy season respectively, with mean values of 6.7 and 7.1 . Thus, $100 \%$ of the samples for both seasons have values $<50 \%$ and this indicates that the water is good for irrigation on the basis of $\mathrm{MH}$.

\section{CONCLUSION}

The hydrochemical facie of the water was determined by plotting the results of the major cations and anions of the analyzed samples on a piper and durov diagrams. The data plots on the Piper diagram indicates that all the water samples fall in the $\mathrm{Ca}^{2+}-\mathrm{Mg}^{2+}-\mathrm{HCO}_{3}{ }^{-}$type, which is typical of fresh water. The plot also shows that weak acid exceeds strong acids and alkaline earth (dominant metal ions) exceeds alkalis. The durov plot supports the fact that $\mathrm{Ca}^{2+}$ $\mathrm{Mg}^{2+}-\mathrm{HCO}_{3}{ }^{-}$water type prevails in the study area. The irrigation indices of SAR, \% Na, PI, KR and $\mathrm{MH}$ were computed in other to determine the suitability of the lake for irrigation and the result shows that all the analyzed samples were suitable for irrigation on the basis of the evaluated indices. It is therefore, recommended that dry season farming should be encouraged in the study area since the quality of the lake for irrigation is excellent in both seasons.

\section{REFERENCES}

[1] Sadashivaiah, C. CRR and GR. Hydrochemical analysis and evaluation of groundwater quality in Tumkur Taluk, Karnataka State,
India. Intl J Environ Res Public Heal. 2008;5(3):158-64.

[2] Singh S.K, Srivastava P.K, Singh D, Han D, Gautam S.K. Modeling groundwater quality over a humid subtropical region using numerical indices, earth observation datasets, and X-ray diffraction technique: a case study of Allahabad district, India. Env Geochem Heal. 2015;37(1):157-80.

[3] Singh S.K, Srivastava P.K, Pandey A.C GS. Integrated assessment of groundwater influenced by a confluence river system: concurrence with remote sensing and geochemical modelling. Water Resour Manag. 2013;27(12):4291-313.

[4] Gautam S.K, Maharana C, Sharma D, Singh A.K, Tripathi JK SS. Evaluation of groundwater quality in the Chotanagpur Plateau region of the Subarnarekha River Basin, Jharkhand State, India. Sustain Water Qual Ecol. 2015;6:57-74.

[5] Nfor B.N. Inventory of Quaternary Geology and the Evolution of the Oguta Lake, Southeastern Nigeria. Quat Int. 2012;279-280:351.

[6] Ahiarakwem C.A, Nwankwor G.I, Onyekuru S.O. An Assessment of the Physical and Environmental Aspects of a Tropical Lake: A Case Studey of the Oguta Lake Watershed, Niger Delta Basin, Nigeria. Am Int J Contemp Res. 2012;2(7):53-60.

[7] Ananaba, S.E, Onu, N.N, and Iwuagwu, C.J., 1993. Geophysical study of the gravel deposits in Ihiagwa, Owerri, Nigeria. Journal of Mining Geology, Vol.29 (2),pp.95-100.

[8] Short K.C, Stauble A.J. Outline of Geology of Niger Delta. Am Assoc Pet Geol Bull. 1967;51.

[9] Ahiarakwem C.A, Onyekuru S.O. A Comparative Assessment of the Physico-Chemical and Microbial Trends in Njaba River, Niger Delta Basin, Southeastern Nigeria. J Water Resour Prot. 2011;03(09):68693.

[10] Okoro B.C, Uzoukwu R.A, Chimezie N.M. River Basins of Imo State for Sustainable Water Resources Management. J Civ Environ Eng. 2014;04(01):1-8.

[11] ALPHA 2005. Standard Methods for the Examination of Water and Wastewater. 23rd edition. Washington, D.C.: American Public Health Association, 2017. Public Health. 2005;(1):1-22.

[12] Piper A. A graphic procedure in the geochemical interpretation of water analyses. Am Geophys Union Trans, . 1994;v.25:914-23.

[13] Todd D.K. Ground Water Hydrology. John Wiley Sons Publ Hoboken, NJ, USA. 1995;3rd edition.

[14] Raghunath. Ground Water:Hydrogeology, Ground Water Survey and Pumping Tests, Rural Water Supply and Irrigation Systems. Vilely Easteren Ltd, New Delhi, India. 1987;2nd edition.

[15] Doneen L.D. Salinization of soils by salt in irrigation water. Am Geophysics Union. 1964;943-950.

[16] Kelly W. Permissible composition and concentration of irrigated waters. Proc Am Soc Civ Eng. 1940;66, 607-613.

[17] Szabolcs .I and C. Darab. The influence of irrigation water of high sodium carbonate content of soils. In: in Proceedings of the 8th International Congress of ISSS. 1964. p. 803-812. 